\title{
Neomycin/Polymyxin B/Bacitracin Zinc Ophthalmic Ointment
}

National Cancer Institute

\section{Source}

National Cancer Institute. Neomycin/Polymyxin B/Bacitracin Zinc Ophthalmic Ointment.

NCl Thesaurus. Code C29287.

A sterile combination preparationscontaining neomycin sulfate, polymyxin B sulfate and bacitracin zinc, as the main active ing redients, for ophthalmic treatments. Polymyxin B sulfate, a polypeptide produced by Bacillus polymyxa, binds to the negatively charged phospholipids in the cell membrane, thereby altering the permeability of the bacterial cytoplasmic membrane. Neomycin sulfate, an aminoglycoside antibiotic, irreversibly binds to the bacterial 30S subunit proteins and 16S rRNA of ribosome, thereby causing misreading and inhibiting protein synthesis which results in bactericidal effect. 